\title{
Increasing Critical Thinking Skill through Class Debate
}

\author{
J. Fuad,I. W. Ardana, Sulton, D. Kuswandi. \\ Universitas Negeri Malang \\ Malang, INDONESIA \\ fuadjauhar@yahoo.co.id
}

\begin{abstract}
Students need critical thinking skills in deciding the various issues that arise with rapid and complex. Critical thinking skills students can thrive in a learning process that encourages their active involvement; both physically and psychologically. Active learning encourages students to listen, speak, read and write. Active learning in the classroom debate, because this method addresses the new theme and controversy, the development of verbal abilities, and writing. This paper intends to examine whether the debate class students' critical thinking skills can be increased? This study uses the one-group pretest-posttest design with a sample of 35 students, and treat use debate method performed 5 times. Data collection techniques using critical thinking skills tests and rating scales. Data analysis using descriptive statistics and test different. The results of this study were (1) that the debate group 4 scored 3.40 keep the first position, followed by group 1 with a value of 3.25 , group 2 with a value of 3.10 Group 5 with a value of 2.93 and group 3 with a value of 2.60; and (2) the ability of critical thinking by $78.93 \%$ students thought exercise categories, with the following indicators: the clarity of information $=80 \%$, the depth of ideas $=75.47 \%$, the breadth of viewpoints $=75.23 \%$, and accuracy in the inference $=85 \%$. Students studying in classroom debate will improve their critical thinking skills with an average difference of pretest and posttest $11.30 \%$ with $t=4.225$ and $p=.000<.05$.
\end{abstract}

Keywords - critical thinking skills, class debate, and active learning.

\section{INTRODUCTION}

Critical thinking is a prerequisite to participate effectively in the various aspects of life. Critical thinking skills include the ability to identify, analyze, evaluate, oral and written arguments; distinguish fact from judgment and knowledge of the faith, and realize the intellectual standards such as accuracy, evidentiary support, clarity and logic [18]. Research has shown the need to improve critical thinking skills among students, because many of them fail to take advantage of reasoning [7].

Nowadays people are not expected to know their place, but to define and position them [23]. When life goes, a supposedly able to make rational decisions based on critical thinking instead of accepting the authority. Therefore, students must be prepared to question the axioms, raises doubts, investigate the situation, and the investigation of alternative, in the context of two schools (colleges) and everyday life [14]. Critical thinking skills is an ability that is essential for life, work and function effectively in all other aspects of life [20] [21] [19] [11] [28] [6].
Students learn more effectively by actively analyze, discuss, and apply content. Active learning involves students doing things and thinking about the things they do. Active learning provides an opportunity for students to speak and listen, read, and write [10]. Useful active learning strategies increase comprehension, retention and critical thinking than passive learning generated from conventional lecture [6]. Using a variety of strategies can help students develop critical thinking skills [28]. That's the learning approach that combines constructivist, active learning, with a student-centered philosophy that the most effective way to improve students' critical thinking [27]. Critical thinking can be enhanced through learning strategies that promote active learning [27] [10] [21] [13] [1]. Methods of debate became one of the methods that emphasize active student involvement. Thus the purpose of this study is to describe a method of learning that can improve critical thinking skills.

\section{LITERATURE REVIEW}

\section{A. Critical Thinking, and Active Learning}

Sutarmo (2012) reveals the ability of critical thinking, the brain is forced to think seriously to solve the problems faced by individuals who thought or think of actions to be carried out later. Therefore, every person has a problem that is not to be avoided, but to be solved, then it should be every person also has the ability to think critically so they can think about what steps should be taken to solve the serious problems they face?. Critical thinking someone will always be active in understanding and analyzing all the information he can get. It can be concluded that the ability of critical thinking is an ability that is essential for every person who is used to solve the problems of life with serious thinking, active, thorough in analyzing all the information they receive to include a rational reason that any action to be taken is correct.

Paul and Elder (2006) describe the development of a person's thinking is a gradual process and adjust a person at a certain level at one level above as an example, think of advanced or superior thinking takes a long time (many years). Critical thinking skills can be seen from the elements of reasoning and intellectual standards of reasoning. Standard intellectual reasoning used is clarity, the logic, depth, and breadth. While the reasoning used element is the information, concepts and ideas, and viewpoints. Thus, it can be formulated into the clarity of information; logical and depth of concepts and ideas; breadth of viewpoint, and clarity in the inference. 
TABLE I

CRITICAL THINKING SKILLS

\begin{tabular}{|c|c|}
\hline Indicator & Criteria Capabilities \\
\hline $\begin{array}{l}\text { Clarity of } \\
\text { information }\end{array}$ & $\begin{array}{l}\text { The information submitted in accordance with the } \\
\text { topic; } \\
\text { The information presented uses simple language and } \\
\text { easy to remember; } \\
\text { Information submitted to sound smooth and clear; } \\
\text { Arguments presented with a clear structure, starting } \\
\text { from the introduction, contents, and conclusions; } \\
\text { Speakers give priority to important issues and } \\
\text { discuss issues that are important later, }\end{array}$ \\
\hline Depth ideas & $\begin{array}{l}\text { The existence of the conformity of ideas on the } \\
\text { topic, along with facts and examples; } \\
\text { Speakers identified the root of the problem; } \\
\text { The speaker proposed a solution that could answer } \\
\text { the root of the problem; } \\
\text { Arguments speaker as a team to build the same idea; } \\
\text { All the arguments submitted in the compact speaker, } \\
\text { an orderly, clear and thorough; } \\
\text { Consistently speaker makes arguments accurate and } \\
\text { supported by appropriate evidence; } \\
\text { Speaker in answering rebuttal arguments with } \\
\text { evidence, facts and examples, }\end{array}$ \\
\hline $\begin{array}{l}\text { Breadth } \\
\text { viewpoint }\end{array}$ & $\begin{array}{l}\text { The main topics are divided into sub-topics; } \\
\text { The first speaker presented the argument that is a } \\
\text { part; } \\
\text { The second speaker portion of the arguments } \\
\text { presented; } \\
\text { The third speaker presented the argument that is a } \\
\text { part; } \\
\text { There is no overlap arguments presented three } \\
\text { speakers; } \\
\text { The speaker can play an active role by offering } \\
\text { interruptions; } \\
\text { If the interrupt is rejected, the speaker offers a } \\
\text { return; } \\
\text { Speaker arguments in answering the interruption } \\
\text { accompanied by facts and evidence; } \\
\text { The answer to the submitted brief interruptions, } \\
\text { solid, and clear, }\end{array}$ \\
\hline $\begin{array}{l}\text { Accuracy } \\
\text { inference }\end{array}$ & $\begin{array}{l}\text { The speaker concluded cover the main issues in the } \\
\text { talks; } \\
\text { Speaker cover between the sound consistent with } \\
\text { the conclusions of the initial statement / cover are } \\
\text { made; } \\
\text { Speakers consistent with the first view of the issues } \\
\text { at stake; } \\
\text { Speakers cover discuss the issues that have been } \\
\text { discussed three previous speakers. }\end{array}$ \\
\hline
\end{tabular}

While critical thinking skills are referred to in this article in a student's ability to explain, argue, conclude based on the evidence. Critical thinking is the ability to argue in an organized manner, the ability to systematically evaluate the weight of their own and other people's opinions, analyzes or ideas towards more specific, distinguishes sharply, choose, identify, assess and develop towards a more perfect, Critical thinking skills no other is the ability of students to gather information and make an evaluative conclusion of various information.

\section{B. Class Debate}

Debate has some format that is used in learning. Tessier (2009) showed that the debate format classroom affect student learning. Regardless of the format, debate classes improve learning skills. Therefore, the debate as an effective tool for achieving academic goals. Students are able to integrate the facts of the debate and apply them on the topic of sustainability.

Tessier (2009) describes the process of debate carried out in a way; teachers asking questions, and there are prizes for the students who won the debate. Teachers act as a moderator in the debate class. This award is given so that students eager to conduct the debate in developing the skills they argue, using the Internet as a primary source, and put confidence in reading sources. Further Tessier (2009) outlines some debate format among them; (1) a standard format, in this case the students involved in the debate asking questions of each other; (2) The panel format, students involved in the debate given the questions, finding answers to questions, the author of the report and present their findings as a class panel; (3) the format of student questions, each party was given the time to give the opening and closing of the debate surrounding the statement, then answer questions provided in advance of the report's authors and the counter field of the opposing party during class; (4) pre-set questions, during a debate in the classroom, each party give an opening statement, asking new questions of authors of the report, debated openly with the opposition, and give closing statements.

Tumposky (2004) asserted that the debate reinforces the two viewpoints. Roy and Macchiette (2005) describes two teams that play a role in the debate so that the focus on the similarities and not the similarity of the topics covered. Hopkins (2003b) most debate comes just two views, however there may be some viable solutions or only one point of view is maintained. Normally a student or team of two or three students defended either positive or negative side of the resolution through speeches and rebuttals. Musselman (2004) describes the debate not only on the two sets of views with 2-3 students to be conciliators in each debate. The debate gave rise to the position of conciliator offer alternative positions or reconcile the two positions. Crone (1997) has students representing three different views in any debate in introductory sociology class at Hanover College.

Another model developed in the format of the debate is a debate four sides. Hopkins (2003a) four sides of the debate, students reflects on what they think about the statement and then moved to one of the four corners of the room, which is labeled "strongly agree", "agree", "disagree" and "strongly disagree". The students who chose the same angle and then work together to present arguments for their positions. After each group maintains its position, students can switch positions if their opinion has changed. Then each working group to write a paragraph summarizing the four strongest arguments for their positions. Walker and Warhurst (2000) cites two students of international management illustrates that participation in the debate does not always produce the mentality of dualistic: "In the end it is not always yes and no, it is always looking for the middle path" and "You learn to look at the gray, it's not necessarily black and white... You are aware of both sides."

Debate is a multi-school activities because the main task involving research, writing, speaking, listening, and teamwork [2]. The students on this course believe that participating in and observing in class debates greatly increase their knowledge of the issues surrounding the topics discussed in the debate [11]. Thus, from several pastures above that learning the study results in the form of critical thinking skills, the learning process using the method of debate. 


\section{MATERIALS AND METHODS}

\section{A. The Study Design}

This research is a subject with a single experimental one-group pretest-posttest design. Treatment studies performed 5 times customize the theme being debated. The sample in this study was 35 students, college level. Students are divided into 5 groups, each group consisting of 6 students (divided into 3 students are the pros and cons of 3 students), so in this debate class requires 30 students. While the 5 students who did not get the group acts as an independent assessor.

\section{B. Treatment}

Each debate consists of two propositions and opposition teams, each consisting of three people. Speech sequence is as follows: (1) the first speaker proposition - 8 minutes; (2) The first speaker of the opposition - 8 minutes; (3) The second speaker propositions - 8 minutes; (4) The second opposition speaker - 8 minutes; (5) The third speaker proposition - 8 minutes; (6) The third speaker of opposition - 8 minutes; (7) the closing speech of opposition - 4 minutes; and (8) the closing speech proposition - 4 minutes.

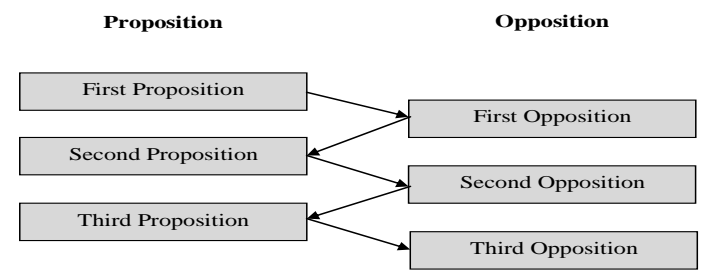

Fig. 1. Process Debate on the format of the World Schools Style

Closing speech (speech reply) delivered by the first or second speaker of each team (not to be the third speaker) and is preceded by the opposition and closed by the proposition. Rules for interruptions (Points of Information - POI) can only be given between 1 minute and 7 on the main speech and no POI in a closing speech.

TABLE II. DEBATE PRocedure

\begin{tabular}{|c|c|}
\hline Stage & Details of Activities \\
\hline Preparation & $\begin{array}{l}\text { Lecturer imposes limits debate topic, } \\
\text { Lecturer identifying learning outcomes that should } \\
\text { be controlled by the participant (concepts, } \\
\text { principles, laws, and theories), } \\
\text { Students learn the topics that will be debated, } \\
\text { Students assign it to the participants to be: the first } \\
\text { speaker, the second speaker and the third speaker, }\end{array}$ \\
\hline Implementation & $\begin{array}{l}\text { Speaker } \\
\text { The first speaker, second, and third is given } 8 \\
\text { minutes with the provisions is as follows: } \\
\text { In the first minute, Timekeeper will give you the } \\
\text { code in the form of a knock as much as } 1 \text { (one) } \\
\text { times to indicate that the interruptions had to do. } \\
\text { At the } 7 \text { th minute, Timekeeper will give you the } \\
\text { code in the form of a knock as much as } 1 \text { (one) } \\
\text { times to indicate that the interruption was not made. } \\
\text { In the minutes All } 7 \text { through } 40 \text { seconds, } \\
\text { Timekeeper will give you the code in the form of a } \\
\text { knock as much as two (2) times to indicate that the } \\
\text { time to explain the argument has been completed } \\
\text { In the } 8 \text { th minute, Timekeeper will give you the } \\
\text { code in the form of a knock continuously until the } \\
\text { speaker completed the delivery of the argument to } \\
\text { indicate that the speaker has exceeded the allotted } \\
\text { time. } \\
\text { The speaker cover gives a time of } 4 \text { minutes, the } \\
\text { provision is as follows: } \\
\text { In the minute-1 and 3rd Timekeeper will give a }\end{array}$ \\
\hline
\end{tabular}

\begin{tabular}{|l|l|}
\hline code to the speaker about the time it has been used \\
by doing a one (1) beats. \\
In the 3rd minute 40 seconds through Timekeeper \\
will give you the code in the form of a knock as \\
much as two (2) times to indicate that the time to \\
explain the argument has been completed. \\
In the 4th minute, Timekeeper will give you the \\
code in the form of a knock continuously until the \\
speaker completed the delivery of the argument to \\
indicate that the speaker has exceeded the allotted \\
time. \\
Interruptions \\
Participants are allowed to submit Interruptions \\
between minute 1 to minute 7 when the speaker is \\
describing his argument. \\
Interruptions referred to in pounds (1) is prohibited \\
when the speaker cover is conducting the exposure. \\
The maximum time for delivering Interrupt is thirty \\
(30) seconds. \\
Interruptions which exceeded the time limit of 30 \\
seconds will be terminated by the chairperson. \\
Type Interrupt must be done by raising hands while \\
standing. \\
Interruptions with the permission of the speaker. \\
Conclusion The debate presented by the lecturer: \\
Provides trip debate \\
Summing back what was disputed by the two \\
groups,
\end{tabular}

Debate class is divided into two parts; debate team and the audience. Debate team acts as a speaker to the position in front of the class, the audience as a listener and pay attention to the course of the debate. This debate is led by a moderator who acts set time. The arrangement of space in the class debate as follows:

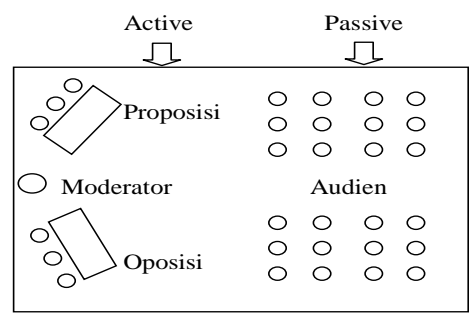

Fig. 2. Seating on the debate format World Schools

Audiences in the execution of the debate are passive (not intervened or filed interruptions). Audience instrumental listens and evaluate the course of the class debate by providing assessments. Audience (the team that does not appear or have appeared) was given the role to assess the team who are conducting a debate session either on the team or the opposition proposition. They assess the trip debate on the two teams in front.

The moderator has the rule sets the course of the class debate to proceed smoothly. He was instrumental in arranging a time and give the opportunity to the opposing team who filed interruptions. In addition, the moderator has a role to pass judgment on the two teams that appear in front. Assessing critical thinking skills used by the moderator and the audience are the same instrument.

\section{Data Collection and Analysis}

Collecting data using tests and rating scales. Critical thinking skills test given before and after treatment. While rating scales used to look at the journey of the debate on each group in each theme.

Data were analyzed using descriptive statistics and test different. Descriptive analysis conducted by the authors 
classifies the data for each category in the ability of critical thinking is based on the distribution of existing data by using a scale (Table III).

TABLE III. CATEgORIZING DATA CRITICAL THINKING SKILLS SCORES

\begin{tabular}{|l|l|}
\hline Level Critical Thinking skills & \multicolumn{1}{c|}{ Category } \\
\hline $100 \%-81 \%$ & Further thinking \\
\hline $80 \%-61 \%$ & Thinking exercises \\
\hline $60 \%-41 \%$ & Thought starters \\
\hline $40 \%-21 \%$ & Thinking that challenge \\
\hline $21 \%-0 \%$ & Think that is not reflected \\
\hline
\end{tabular}

Data analysis techniques to determine differences in critical thinking skills using the t-test. Decision-making criteria are based on the differences in the level of error of $5 \%$.

\section{RESUlTS AND DISCUSSION}

The following assessment of critical thinking skills in the classroom debate in Table IV. In the process of debate group 4 kept the first position in the category of thought further, one group followed the same category; and group 2, group 5 and group 3 with categories of thought exercises.

TABLE IV. Assessment Process Debate

\begin{tabular}{|l|l|l|l|l|l|}
\hline & $\begin{array}{c}\text { Grou } \\
\text { p 1 }\end{array}$ & $\begin{array}{c}\text { Grou } \\
\text { p 2 }\end{array}$ & $\begin{array}{c}\text { Grou } \\
\mathbf{p ~ 3 ~}\end{array}$ & $\begin{array}{c}\text { Grou } \\
\mathbf{p ~ 4}\end{array}$ & $\begin{array}{c}\text { Grou } \\
\text { p 5 }\end{array}$ \\
\hline $\begin{array}{l}\text { Clarity of } \\
\text { information }\end{array}$ & 3.60 & 3.40 & 2.40 & 3.80 & 3.8 \\
\hline Depth of ideas & 3.20 & 3.50 & 2.80 & 3.60 & 2.6 \\
\hline Breadth viewpoint & 3.10 & 2.60 & 2.80 & 3.30 & 2.5 \\
\hline Precision in inference & 3.10 & 2.90 & 2.40 & 2.90 & 2.8 \\
\hline Mean & 3.25 & 3.10 & 2.60 & 3.40 & 2.93 \\
\hline$\%$ & 81.25 & 77.5 & 65 & 85 & 73.12 \\
\hline
\end{tabular}

Table $\mathrm{V}$ shows that in each indicator of the value of critical thinking skills pretest to posttest values have increased. For example: the indicator increase 12:38\% clarity of information, ideas depths increase $1.9 \%$, the breadth of viewpoints increase 14,05\%, and accuracy in the inference increase $16.9 \%$.

TABLE V. CRITICAL THINKING SKILLS INDICATORS MEAN

\begin{tabular}{|l|l|l|l|l|}
\hline No & \multicolumn{1}{|c|}{ Indicator } & \multicolumn{1}{c|}{ Pretest } & Posttest & Difference \\
\hline 1. & Clarity of information & 67.62 & 80 & 12.38 \\
\hline 2. & Depth of ideas & 73.57 & 75.48 & 1.9 \\
\hline 3. & Breadth viewpoint & 61.19 & 75.24 & 14.05 \\
\hline 4. & Precision in inference & 68.1 & 85 & 16.9 \\
\hline & Mean & 67.62 & 78.93 & 11.309 \\
\hline
\end{tabular}

Table VI and Table VII can be concluded there is a difference between the fastest $=78.93$ and pretest value $=$ 67.62 to see the difference in mean $=11309$. This shows that the method of debate, improving students' critical thinking skills with a value of $\mathrm{t}=4,225$ and $\mathrm{p}=.000$ $<.05$.

TABLE VI. DESCRIPTIVE STATISTICS

\begin{tabular}{|l|c|c|l|}
\hline & \multicolumn{1}{|c|}{ Mean } & N & Std. Deviation \\
\hline posttest & 78.9286 & 35 & 15.88044 \\
\hline Pretest & 67.6190 & 35 & 10.22299 \\
\hline
\end{tabular}

TABLE VII. DIFFERENCE MEAN POSTTEST - PRETEST

\begin{tabular}{|l|c|c|c|}
\hline & Mean & t & p \\
\hline posttest - pretest & 11.309 & 4.225 & .000 \\
\hline
\end{tabular}

This study confirms the results of previous studies. Goodwin (2003) revealed debate requires the use of logic and common sense rather than just free expression of opinions. Participants preparing abilities so that they know what they are talking about. The debate is more suitable for the development of higher order thinking skills of students than traditional learning strategies such as lectures [18] [19] [10] [11] [6]. Debate involving not only determine what to say, but how to say [18]. Gregory and Holloway (2005) argues that the debate over expanding the critical thinking and the ability to argue over the essay. Osborne (2005) reported that a class debate as a fun class and the students participated with a higher percentage in the debate than a less structured discussion.

Roy and Macchiette (2005) reported a debate in the classroom can effectively facilitate critical thinking. Therefore, the debate as a teaching tool, has a place in pedagogical methods because it allows students to enhance their critical thinking through the probe arguments, engaged in research, collecting information, analyzing, assessing arguments, questioning assumptions, and demonstrate interpersonal skills. Furthermore, Roy and Macchiette (2005) describes a method debate is a form of verbal controversy that consists of a systematic presentation of opposing arguments on topics that understood the other party. This process involves a discussion that is contrary to his views by engaging in arguments. Kennedy $(2007 ; 2009)$ revealed the debate has been successfully used in a variety of disciplines including sociology, history, psychology, biotechnology, mathematics, health, dentistry, nursing, marketing, and social work. Scott (2008) suggests that students believe that debates help them understand the topics better, learn new knowledge, and gain an understanding of the process of debate. In addition, students think that the debate increased their critical thinking skills. Hall (2011) method of debate can prepare students to become critical thinkers and effective communicators in a broad environment, and confidence to communicate. Improve critical thinking and problem solving, and develop confidence and respect.

Roy and Macchiette (2005) debate contributes many benefits for students: (1) increase the ability of students to develop a communication strategy alternatives, including the use of techniques nonverbal, (2) instill a sense of teamwork and time management, (3) building confidence for students as they gain experience in public speaking, (4) teachers may also benefit by enriching the classroom experience and interesting. The debate creates a learning environment that is really interesting.

\section{CONCLUSION}

Critical thinking skills become a basic necessity for everyone in running his life. Critical thinking skills can be developed in active learning that involves students actively in the learning process. Active learning can be found in the learning activities of students on the role of its strategic position. The method emphasizes active learning can be found in the methods of debate. This method addresses the new theme and controversy, the development of verbal ability, and others. In some literature study, debate method succeeded in developing the critical thinking skills of students.

Critical thinking related to reasoning. Reasoning is a process that allows one to assess and put forward logical 
arguments. Reasoning is a thinking process that produces knowledge. Verbal reasoning is the ability to think logically in drawing conclusions either inductively or deductively expressed through language as the primary means. Verbal reasoning subtest consists of analogy words, vocabulary, and relationships of words, so that the learning method can foster debate skills students in thinking and speaking. Thus the debate classes can improve students' critical thinking skills on four indicators: clarity of information, depth of ideas, breadth viewpoint and precision in inference.

\section{ACKNOWLEDGMENT}

The author would like to thank the Ministry of Religious Affair Republic of Indonesia, which has been providing financial assistance with study completion.

\section{REFERENCES}

[1] Alexander, M. E., (2010). Using the four-questions technique to enhance critical thinking in online discussions. Merlot Journal of Online Learning and Teaching, 6(2), 409-415.

[2] Allison, S. (2002). Debating with talented and gifted students. School Libraries in Canada, 22(1), 10-14.

[3] Crone, J. (1997). Using panel debates to increase student involvement in the introductory sociology class. Teaching Sociology, 25(3), 214-218.

[4] Goodwin, J. (2003). Students' perspectives on debate exercises in content area classes. Communication Education, 52(2), 157-163.

[5] Gregory, M., and Holloway, M. (2005). The debate as a pedagogic tool in social policy for social work students. Social Work Education, 24(6), 617-637.

[6] Hall, D., (2011). Debate: innovative teaching to enhance critical thinking and communication skills in healthcare professionals. The Internet Journal of Allied Health Sciences and Practice, 9(3), $1-8$.

[7] Halpern, D. F. (1998). Teaching critical thinking for transfer across domains. American Psychologist, 53(9), 449-455.

[8] Hopkins, G. (2003a). Four corner debate. Retrieved Desember 6, 2013, from http:// www.educationworld.com/a_lesson/03/lp30404.shtml

[9] Hopkins, G. (2003b). Stage a debate: A primer for teachers on the Lincoln-Douglas debate format. Retrieved Desember 06, 2013, from ttp://www.educationworld.com/a_lesson/03/lp304-01.shtml

[10] Kennedy, R. R., (2007). In-class debates: fertile ground for active learning and the cultivation of critical thinking and oral communication skills. International Journal of Teaching and Learning in Higher Education, 19(2), 183-190.

[11] Kennedy, R. R., (2009). The power of in-class debates. Active Learning In Higher Education, 10(3). 1-12.

[12] Kuhn, D. (1999). A developmental model of critical thinking. Educational Researcher, 28(1), 16-26.

[13] Mandernach, B. J., Forrest, K.D., Babutzke, J. L., and Manker, L.R., (2009). The role of instructor interactivity in promoting critical thinking in online and face-to-face classrooms. Merlot Journal of Online Learning dnd Teaching, 5(1), 49-62.

[14] Miri, B., David, B-C., and Uri, Z. (2007). Purposely teaching for the promotion of higher-order thinking skills: a case of critical thinking. Research in Science Education, 37: 353-369

[15] Musselman, E. (2004). Using structured debate to achieve autonomous student discussion. The History Teacher, 37(3), 335348.

[16] Osborne, A. (2005). Debate and student development in the history classroom.

[17] Paul, R. dan Elder, L. (2006). Cirtical Thinking: Tool sfor taking charge of your professional and personala life. New Jersey: Financial Time prentice hall upper saddle river.

[18] Roy, A., and Macchiette, B., (2005). Debating the issues: a tool for augmenting critical thinking skills of marketing students. Journal of Marketing Education, 27(3), 264-276.
[19] Scott, S., (2008). Perceptions of students' learning critical thinking through debate in a technology classroom: a case study. The Journal of Technology Studies, 34(1), 39-44.

[20] Simpson, E., and Courtnery, M., (2007). The development of a critical thinking conceptual model to enhance critical thinking skills in middle eastern nurses: a middle eastern experience. Australian Journal Of Advanced Nursing, 25(1), 56-63.

[21] Snyder, L. G., and Snyder, M. J., (2008). Teaching critical thinking and problem solving skills. The Delta Pi Epsilon Journal, 50(2), 90-99.

[22] Sutarmo, S.V., (2012). Otak dan Beberapa Fungsinya. Jakarta: Fakultas Kedokteran UI.

[23] Ten Dam, G., and Volman, M. (2004). Critical thinking as a citizenship competence: teaching strategies. Learning and Instruction, 14(4), 359-379.

[24] Tessier, J. T., (2009). Classroom debate format effect on student learning and revelations about student tendencies. College Teaching, 57(3). 144-152.

[25] Tumposky, N. (2004). The debate debate. Clearing House, 78(2), 52-55.

[26] Walker, M., and Warhurst, C. (2000). "In most classes you sit around very quietly at a table and get lectured at ...”: Debates, assessment, and student learning. Teaching in Higher Education, 5(1), 33-49.

[27] Walker, S.E. (2003). Active learning strategies to promote critical thinking. Journal of Athletic Training, 38 (3), 263-267.

[28] Yildirim, B and Ozkahraman, S., (2011). Critical thinking in nursing process and education. International Journal of Humanities and Social Science, 1(13), 257-262. 